\title{
Southern African Development Coordination : Toward a Functioning Dynamic?
}

We are gathered here today to try to chart a new course for the future of Southern Africa, or to launch a new type of struggle for liberation - economic liberation. . . our colonial past has ensured that we will continue to depend on others for our economic survival. . . some of the countries on which some of us depend for our economic survival do not share the ideals on which our own societies are founded. Unfortunately, we find ourselves at their mercy. We have to deal with them while condemning them for their evil policies. I believe, nevertheless, that there is a way out of our dilemma. . . we can wage a successful struggle for economic liberation provided we can begin now, in the free states of Southern Africa, to plan together for our economic future.

[President Seretse Khama 1979]

\section{Collective Self-reliance : a Renewed Initia-} tive?

Collective self-reliance (economic cooperation among developing countries - ECDC - or economic integration) seemed to be in the doldrums in the mid-1970s. Nowhere was this more true than in Africa, with the collapse of the East African Community (EAC) and the very slow progess made in launching the Economic Community of West Africa States (ECOWAS) [Vaitsos 1979; Renninger 1978; Green 1976-77, 1977-78, 1979].

However, with new ideas on how common interests (rather than common markets) might form a basis for active coordination measures [UNCTAD 1976; Oteiza and Rahman 1978], there has been renewed interest at political and political/economic as well as technical/economic and intellectual levels. Moreover, with western countries - for

\footnotetext{
1 Dr Green was a member of the Southern Africa Development Coordination Conference (SADCC) Conmittee and of the Arusha SADCC Secretariat and is a member of the continuing SADC London Liaison Committee. However, the views expressed are his personal responsibility and are not necessa rily those of the SADCC participants or of the Front Line States who convened the conference.
}

whatever reasons - clearly unwilling or unable to negotiate significant international economic order changes, the Group of 771979 pre-UNCTAD ministerial meeting made collective self-reliance a centre piece for its meetings and programmes [UNCTAD 1979].

Southern Africa (ie the independent states from Tanzania and Angola southward) is at first glance a startling area for such initiatives. A classic common market approach would not be feasible - trade area short run potential is low, inequalities in competitiveness are high, foreign exchange constraints are endemic for the larger states. Nor does the alternative of complete economic integration seem plausible - political economic ideologies, structures of production, levels of productive forces and styles of state economic intervention are too different. There is no historic experience of economic union among these states and very bitter memories of two past (EAC, Central African Federation) and one continuing (South African Customs Union) economic integration scheme. These are perceived as externally designed and immiserising for several of the Southern African states.

However, in July 1979 - after an extended period of political, official and technical preparation - the Front Line States (Tanzania, Mozambique, Zambia, Botswana, Angola) held a ministerial meeting on Southern African Development Coordination convened by President Khama of Botswana and held in Arusha. That meeting identified a set of common interests, sectors for coordinated action and means of acting. Why was this possible? What is likely to come of it?

Economic cooperation between developing countries (ECDC) rests on perceived common interests which participating states believe can be pursued more effectively collectively than separately. In the case of Southern Africa the common interest is very clear - reduction of economic dependence on, and weakness vis-à-vis, the Republic of South Africa.

The Conference Chairman, Vice-President Masire of Botswana, summarised the goals in his Opening Statement [SADCC 1979a]: 
- the reduction of economic dependence, particularly on the Republic of South Africa;

- the forging of links to create a genuine and equitable integration:

- the mobilisation of resources to promote national, interstate and regional policies;

- concerted action to secure international cooperation within the framework of a strategy for economic liberation.

The sponsorship of the conference by the Front Line States (FLS) is a demonstration of the fact that successful coordination on one set of issues creates the potential for coordination on others. As President Seretse Khama and Chairman Masire put it:

The Five Front Line States have already shown that cooperation is possible among the independent states of Southern Africa regardless of their different ideologies and economic systems. We have been working harmoniously together to evoke common political problems and I see no reason why we cannot work together harmoniously to solve common economic problems. Precisely because of the progress on the political front of the liberation struggle, it is now both possible and necessary to include economic liberation in the programmes and priorities of the Front Line States. We must free our economies from their dependence on the Republic of South Africa, overcome their imposed economic fragmentation, and coordinate our regional and national development.

[SADCC 1979b]

The FLS members have substantial experience in bilateral cooperation. Between 1965 and 1975 . Tanzania/Zambia joint transport investment to reduce dependence on Rhodesian rebel controlled routes absorbed over a quarter of Tanzania's total gross fixed investment and perhaps as much of Zambia's. Mozambique has special commissions and/or transport subcommissions with Swaziland, Malawi, Zambia, Angola and Tanzania. Tanzania/Mozambique cooperation includes a successful bilateral trade plan, transport coordination and preparation of a series of Rovuma River basin development projects. Botswana has made use of places in specialised educational institutions in several other Southern African states. The list is neither short nor trivial, even if it includes no precursor to a common market or an economic union.

However, the experience of bilateral cooperation has also revealed its limitation. This is most evident in transport. The crisis confronting Zambia is a regional problem. Effective coordination of capacity and freight allocation among Angolan, Mozambican, Zimbabwean, Malawian and Tanzanian routes can be developed and joint programmes for rehabilition and capacity utilisation articulated and acted upon, only on a regional basis. Similarly, the Botnam (TransKalahari) Railway will concern the region - not just Botswana and Namibia. Botswana needs the Botnam to develop its coal, soda ash, Okavango water and crop and copper potential, and to gain access to the Atlantic. Namibia needs it to replace smelter coal now coming from South Africa. But Zambia and more particularly - Zimbabwe, with the prospects for massive coal exports to Europe and Latin America by 1990 , are also concerned. So is Mozambique, which must plan port and rail expansion to handle Indian Ocean-directed Zambian and Zimbabwean tonnage.

There has also been a more reactive factor. Several outside bodies - eg USAID [1979] and the EEC have begun to study Southern Africa as a region. This has been perceived by some FLS officials and decision-takers as requiring the Southern African states to have their own regional plan. Otherwise they would be 'planned for' from outside. If there is a Southern African strategy, outside cooperation is welcome within it. Otherwise 'regional planning' can be only divisive and another stage in foreign penetration.

Finally, there is the common concern for breaking out of present economic dependence (except for Angola and Tanzania) on South Africa; and of joint action to replace RSA linkages with independent Southern African ones. Commitment to that goal, not FLS membership, was seen as the criteria for SADC participation:

the initiative toward economic liberation has flowed from our experience of joint action for political liberation; but regional economic coordination is not exclusive. It is open to all genuinely independent African States. In addition, in many fields, notably transport, observer status will be open to Liberation Movements wishing to participate in anticipation of genuine independence. Similarly, in manpower development and research, the involvement of Liberation Movements is necessary to amass the knowledge and train the personnel who will be essential once political liberation is achieved.

[SADCC 1979a]

The initial priority sector for SADC is to be transport and communications. When Namibia is independent, six of the 10 regional states will be 
landlocked, transit revenues will be critical to one and significant to two, while the last is a logical access route to the Atlantic for two landlocked states. The old integration of rail, road, air and telecommunications centred on the Republic (and its then satellite port of Lourenço Marques) with a semi-separate sub-system centring on Southern Rhodesia. Despite massive efforts since the Rhodesian rebellion began in 1965 , much of that dependence remains. Four states are dependent on traffic via South Africa and South African transit revenues are critical to Mozambique. Angola faces severe problems resulting from South African supported insurgency, while Tanzania has to cope with Zambian traffic. Air and communications links within the region are, to put it mildly, inadequate - the quickest route is usually via Johannesburg.

Transport is crucial because all the economies are dependent on trade external to the region. Further domestic development - specially in Botswana, Namibia, Mozambique and Angola - requires new routes which have major potential interstate significance. And with present regional fragmentation and South African links, coordination of production and trade is very much handicapped:

key to this strategy are transport and communication. The dominance of the Republic of South Africa has been reinforced and strengthened by its transport system. Without the establishment of an adequate regional transport and communications system, other areas of cooperation are not feasible. Therefore, the Front Line States intend to create a Regional Transport and Communications Commission to coordinate the use of existing systems and the planning and financing of additional regional facilities.

[SADCC 1979a]

Several other sectors were sketched in less detail. In respect to trade, the Mozambique/Tanzania approach of annual trade plans (budgets) identifying target levels, volumes and values of commodities was cited as potentially fruitful. The need to base trade on production - not the other way around - was asserted. Fertiliser and fertiliser feed stocks (Mozambique), African strain foot-andmouth vaccine (Botswana) and the Tinkabi tractor (Swaziland) were among the products cited as examples of possible joint production/trade coordination.

In respect to finance, the initial intention is to convene a pledging conference once the Transport and Communications Commission has canvassed requirements for rehabilitation, expansion and new projects, set priorities, secured feasibility studies and agreed a pattern of national investment. ${ }^{2}$ Whether, subsequently, to set up a Special Fund in association with the African Development Bank or to build up a fully fledged Regional Development Bank remains under consideration.

Education and research received attention as areas requiring coordination. Again the approach was unusual. In respect to education, while recognising the possible value of some common institutions, the emphasis was on coordinated use of national institutions in such fields as mining engineering, mining technology and wildlife management. This would involve exchange of data on facilities, courses, requirements and schedules in each state, and some means to allow assured numbers of places (and candidates) over several years. In research there was the same general approach: exchange of information on programmes and results, and co-ordination to limit duplication and ensure that programmes covered issues of interest to several states.

Mining - the key export sector in most of the economies - was seen as offering scope for joint exploration and for coordination of national policies in respect to mineral rights, contracts, taxes and ownership shares to ensure that the Southern African countries presented a joint front to large companies, and to prevent such companies from playing off countries against each other. The value of a data pool and of regional specialist teams perhaps based on ECAs Mining Bureau in Dodoma - received attention.

The immediate issues in the power and energy sector were seen as the oil supply and price for states now dependent on South Africa. Regional or sub-regional hydropower grids were seen as a longer-term field for coordinated action.

Environmental protection and food security initially suggested by Conference members from outside the region ${ }^{3}$ - were perceived as areas of concern, but lines of action were not clear. Antidesertification and arid agriculture development (helped by a regional centre of the International Centre for Research in Agriculture in the SemiArid Tropics - ICRASAT) were included under research. Coordination of national grain reserves and emergency intra-regional food loans (like that

\footnotetext{
2 Scheduled for Maputo in November 1980.

${ }^{3}$ In effect there were two conferences - one by FLS ministers and the second also including individuals from the United Nations, UNDP, ECA, the Commonwealth Secretariat and major multinational and national economic cooperation bodies.
} 
from Tanzania to Mozambique) were seen as desirable, but limited by the fact that of the FLS only Tanzania at present has even a small staple grain surplus.

The stress at SADCC was on coordinated, planned, open initiatives. The chairman, echoing a longer comment by Tanzanian Minister Edwin Mtei underlined the high priority set on speedy, concrete regional action to supplement and coordinate national efforts.

There were several clear sub-themes:

- past experience had created reservations about large multinational institutions;

- complex structure building - and long institution drafting - would delay initial action, require personnel the states could not spare, and be premature, at least until patterns and requirements of coordination were more clearly defined;

- arrangements based on national units coordinating through joint commissions with very limited staffs of their own were preferred as flexible, effective instruments based on national goals and plans, but able to understand and agree how to implement common interests.

Coupled with an aversion to an elaborate regional superstructure, there was a clear unwillingness to create a laissez faire regional frame for coordinating interventionist state policies. The regional contribution was seen as that of supplementing and coordinating national plans. It was not thought of in terms either of a supranational planning unit or of a free market, since either would inevitably collide with national actions and prevent, rather than facilitate, identifying and acting on common interests.

In the autumn of 1979 the FLS Heads of State held a meeting on the results of the Arusha conference. They decided that the next step should be a broader Heads of State meeting of all independent Southern African countries. This meeting was convened by President Seretse Khama of Botswana in Lusaka during April 1980. While the delay in pressing ahead after Arusha may seem to have led to a loss of momentum it has enabled independent Zimbabwe to be involved from the start. The test of whether principles and analysis will lead to meaningful action is likely to come over the next 18 months.

SADCCs approach was very open - precisely because of its emphasis on coordination (not unification) and common interests:
- open to Swaziland, Lesotho, Malawi and, when genuinely independent, Zimbabwe and Namibia;

- open to any participating state to take part in some programmes and projects and not others ie a clear rejection of the 'all or nothing' approach which has hampered some schemes for economic union;

- open to a SADC state to have special arrangements with its neighbours not under the SADC umbrella, eg Tanzania/Rwanda/Burundi (and perhaps now Uganda) in the Kagera Basin Scheme; Zambia/Angola/Zaire in respect to the Lobito Bay railway. Because of the non-common market approach to trade and the priority given to transport, the SADCC approach, unlike most previous initiatives for regional integration, was consistent with such possibilities.

In a different sense SADCC was relatively closed. The FLS did not import from outside the region either an academic or a political approach to integration. They looked at their own situation, at background papers and at outside suggestions, and sought to outline a Southern African way forward.

The same holds true in respect of possible external partners in cooperation. They were invited to Arusha to discuss as well as listen. But as Mozambican Minister Rui Baltazar Santos stated at the conference:

the establishment of cooperation in new moulds requires, on the part of the developed countries, a deeper knowledge of the African reality and, in particular, of Southern Africa. It equally requires the recognition that the African peoples have the capacity to manage their own interests, without disagreeable pressures or interferences made against their dignity, freedom and independence.

The emphasis was clear - cooperation with the regional strategy was welcome, external planning for the region was not. Cooperation, yes cooptation, no.

\section{Reflections}

It is too early to foresee clearly the nature or pace of results flowing from the Arusha conference. The initial proposals are positive but Southern Africa is short of foreign exchange and personnel and long on pressing problems and urgent issues. Projections tend to underestimate time lags and limitations.

However, the SADCC approach has already made a contribution to re-thinking ECDC by its radical departures from both the common market and the integrated community approaches: 
- the lead sector is not trade, but transport and communications;

- decisions were made on the basis of perceived common needs and interests, not from historic inheritance or on outside advice;

- the thinking on trade seems to be toward planned-selective-targeted, not laissez faire, exchange:

- coordination based on national planning, not market determination or a supranational planning body, has been seen as the central institutional mechanism;

- while expatriate consultants were used in preparing materials, the basic conceptual approach was very much Southern African - witness its departure from much 'received wisdom' on ECDC models. ${ }^{4}$

Given the importance of the meeting, as demonstrated by the high level FLS participation, the Chairman's concluding remarks need to be taken seriously as a guide to what will be attempted:

until our economies are free from the domination of the Republic of South Africa and linked regionally with one another we cannot go forward with assurance or in safety. We must ensure that the efforts of our people to achieve development. to meet their basic human needs are in a setting which gives them the greatest measure of success. That setting is Southern African regional development coordination... we have affirmed our determination to set out on the long journey to economic liberation on a regional level... We believe that we have taken that first step and have taken it in the right direction.

[SADCC 1979c]

\section{Footnotes : Lusaka and After}

Since Arusha South Africa's attempt to pursue its longstanding economic outreach policy in the new form of 'Constellation of States' [Geldenhuys and Venter 1979; Green 1980] has broken against the opting out of every independent state and the ZANU-PF victory in Zimbabwe. The Lusaka SADCC summit of April 1980 was attended by the Presidents of Angola, Botswana (Chairman), Mozambique, Tanzania and Zambia, the Prime Ministers of Zimbabwe and Swaziland and senior ministers from Lesotho and Malawi. SWAPO's President participated as an official observer.

\footnotetext{
4 The ECA concentration on a preferential trade area for East and Central Africa as a first step toward a regional free trade area is in the classic, laissez faire tradition. The lack of attention given to it at SADCC - the fact that Mozambique, Tanzania and Angola have very great reservations about it and Botswana, Lesotho and Swaziland cannot really implement it so long as they remain in the South African Customs Union suggests that FLS economic ministers do not see it as either a necessary or a sufficient condition for ECDC in Southern Africa.
}

The Lusaka Summit's official interstate declaration 'Southern Africa Toward Economic Liberation' [SADCC, 1980] affirmed and adopted the themes of the Arusha Conference. It created the Transport and Communications Commission based in Maputo and assigned eight other areas (later raised to nine) to six (later seven), other states to prepare detailed proposals to a September Ministerial Meeting in Zimbabwe.

\section{References}

Geldenhuys, D. and D. Venter, 1979, 'Regional Cooperation in Southern Africa: A Constellation of States', International Affairs Bulletin. South African Institute of International Relations, December

Green, R. H., 1976-77, 'The East African Community: the end of the road', Africa Contemporary Record, Africana, London

- 1977-78, 'The East African Community: death, funeral, inheritance', Africa Contemporary Record, Africana, London

- 1979, 'Toward Southern African regionalism', Africa Contemporary Record, Africana, London

- 1980, 'Constellation, Association, Liberation: The Struggle for Southern African Development Coordination', Africa Contemporary Record. Africana, London

Oteiza, E. and A. Rahman, 1978, Technical Cooperation among Third World Countries and the International Order, Third World Forum, Colombo

Renninger, J. P., 1978, Multinational Cooperation for Development in West Africa, Pergamon, New York

SADCC 1979a, Opening Statement (by VicePresident Masire of Botswana)

- 1979b, Keynote Address (by President Khama and Vice-President Masire)

- 1979c, Closing Statement

- , 1980 Southern Africa: Toward Economic Liberation. A Declaration by the Governments of Independent States Of Southern Africa made at Lusaka, April 1 
UNCTAD, 1976, Economic Cooperation among Developing Countries, (Expert Group Report), Geneva

- 1979, Arusha Programme for Collective SelfReliance and Framework for Negotiations, Geneva, TD/236
USAID, 1979, Development Needs and Opportunities for Cooperation in Southern Africa. Washington

Vaitsos, C., 1979, 'Crisis in regional economic cooperation among developing countries', World Development 